OPEN ACCESS

Edited by:

Jorge Blanco,

Universidade de Santiago de

Compostela, Spain

Reviewed by:

Frieder Schaumburg, Universitätsklinikum Münster,

Germany

María Guembe

Hospital General Universitario

Gregorio Marañón, Spain

QingZhong Liu,

Shanghai Jiao Tong University,

China

*Correspondence:

Esther Viedma

ester.viedma@salud.madrid.org

tThese authors have contributed equally to this work

Specialty section: This article was submitted to

Infectious Diseases,

a section of the journal

Frontiers in Microbiology

Received: 22 June 2018

Accepted: 29 August 2018

Published: 25 September 2018

Citation:

Pérez-Montarelo D, Viedma E,

Larrosa N, Gómez-González C

Ruiz de Gopegui E, Muñoz-Gallego I,

San Juan R, Fernández-Hidalgo N,

Almirante B and Chaves F (2018)

Molecular Epidemiology of

Staphylococcus aureus Bacteremia: Association of Molecular Factors With

the Source of Infection.

Front. Microbiol. 9:2210.

doi: 10.3389/fmicb.2018.02210

\section{Molecular Epidemiology of Staphylococcus aureus Bacteremia: Association of Molecular Factors With the Source of Infection}

\author{
Dafne Pérez-Montarelo ${ }^{1 \dagger}$, Esther Viedma ${ }^{1 * \dagger}$, Nieves Larrosa ${ }^{2}$, Carmen Gómez-González ${ }^{3}$, \\ Enrique Ruiz de Gopegui ${ }^{4}$, Irene Muñoz-Gallego ${ }^{1}$, Rafael San Juan ${ }^{1}$, \\ Nuria Fernández-Hidalgo ${ }^{2}$, Benito Almirante ${ }^{2}$ and Fernando Chaves ${ }^{1}$ \\ ${ }^{1}$ Hospital Universitario 12 de Octubre, Madrid, Spain, ${ }^{2}$ Hospital Universitario Vall d'Hebron, Barcelona, Spain, ${ }^{3}$ Hospital \\ Galdakao-Usansolo, Galdakao, Spain, ${ }^{4}$ Hospital Universitario Son Espases, Palma de Mallorca, Spain
}

Staphylococcus aureus bacteremia (SAB) is associated with high morbidity and mortality, which varies depending on the source of infection. Nevertheless, the global molecular epidemiology of SAB and its possible association with specific virulence factors remains unclear. Using DNA microarrays, a total of 833 S. aureus strains (785 SAB and 48 colonizing strains) collected in Spain over a period of 15 years (2002-2017) were characterized to determine clonal complex (CC), agr type and repertoire of resistance and virulence genes in order to provide an epidemiological overview of CCs causing bloodstream infection, and to analyze possible associations between virulence genes and the most common sources of bacteremia. The results were also analyzed by acquisition (healthcare-associated [HA] and community-acquired [CA]), methicillin-resistant (MRSA) and methicillin-susceptible (MSSA) strains, and patient age (adults vs. children). Our results revealed high clonal diversity among SAB strains with up to 28 different CCs. The most prevalent CCs were CC5 (30.8\%), CC30 (20.3\%), CC45 (8.3\%), CC8 (8.4\%), CC15 (7.5\%), and CC22 (5.9\%), which together accounted for $80 \%$ of all cases. A higher proportion of CC5 was found among HA strains than CA strains (35.6 vs. $20.2 \%, p<0.001)$. CC5 was associated with methicillin resistance (14.7 vs. $79.4 \%$, $p<0.001$ ), whereas CC30, CC45, and CC15 were correlated with MSSA strains $(p<0.001)$. Pathogen-related molecular markers significantly associated with a specific source of bacteremia included the presence of sea, undisrupted hlb and isaB genes with catheter-related bacteremia; sed, splE, and fib genes with endocarditis; undisrupted hlb with skin and soft tissue infections; and finally, CC5, msrA resistance gene and hla gene with osteoarticular source. Our study suggests an association between $S$. aureus genotype and place of acquisition, methicillin resistance and sources of bloodstream infection, and provides a valuable starting point for further research insights into intrinsic pathogenic mechanisms involved in the development of SAB.

Keywords: Staphylococcus aureus bacteremia, bacteremia source, molecular epidemiology, clonal complex, virulence factors 


\section{INTRODUCTION}

Staphylococcus aureus is an opportunistic pathogen that can potentially cause a wide range of infections. It is a leading cause of bacteremia and represents a significant global health problem (Weiner et al., 2016). S. aureus bacteremia (SAB) is often associated with severe metastatic infections, such as infective endocarditis, septic arthritis and osteomyelitis and complications, such as sepsis and septic shock, which lead to adverse outcomes that are challenging to manage (Shorr et al., 2006; Wyllie, 2006).

The incidence of $\mathrm{SAB}$ is difficult to determine and there are major geographical differences that reflect discrepancies in health care systems and infection control practices. In developed countries, the estimated incidence $80-190$ cases per 100,000 inhabitants per year (Laupland, 2013; Le Moing et al., 2015). Despite the improvements in SAB management, including greater understanding of this infection and mandatory surveillance implemented in several countries over recent decades, SAB still causes significant morbidity and mortality, with an associated early mortality that appears to have plateaued at approximately 20-30\% (van Hal et al., 2012). Certainly, little is known about global SAB epidemiology in terms of the circulating clones causing $\mathrm{SAB}$ in different patient subgroups, such as adults and children, or those most commonly found in the community or hospital settings. Because it is becoming progressively more difficult to differentiate between healthcareassociated and community-acquired infections due to changes in the complexity of present health care systems, it is important to identify the specific clones that are traditionally associated with the community but may be entering hospitals and replacing common nosocomial clones, and vice versa. Moreover, it would be especially interesting to study clonality taking into account that bacterial phenotype and genotype have been shown to have a possible influence on infection outcome, since different clones can adopt different strategies to overcome host responses and cause severe pathology (Recker et al., 2017). The overall mortality rate from SAB varies depending on the primary focus of infection (the highest rates occur in patients with infective endocarditis and pulmonary infections, and the lowest in patients with catheter-related infections) and on the complications deriving from SAB. This association makes it necessary to regard SAB not as a single entity, but as a heterogeneous group of infections that can evolve differently and therefore require source-specific management (van Hal et al., 2012). However, the characteristics of the most common clones causing $\mathrm{SAB}$ according to source of infection remain unknown. Furthermore, determining the role of particular genetic backgrounds (clonality and virulence) in bloodstream infections caused by $S$. aureus has become a real challenge due to the diversity, redundancy and host specificity of the virulence factors.

The aim of the present study was to explore the molecular characteristics of $S$. aureus strains causing bacteremia in order to provide an epidemiological overview of the circulating clones causing bloodstream infection and to analyze the possible association between virulence and the most common sources of bacteremia.

\section{MATERIALS AND METHODS}

\section{Data Collection}

A total of 785 strains causing bacteremia with different source and 48 colonization strains collected over a period of 15 years (2002-2017) were analyzed. These strains were obtained from different sources in hospitals geographically distant from each other spread across the territory of Spain (Table 1). Specifically, these strains were identified in 10 different collections: six were single-center studies developed at the Hospital 12 de Octubre in Madrid, and the remaining four corresponded to multi-center studies developed at various Spanish hospitals (Muñoz-Gallego et al., 2017; San-Juan et al., 2017; FernándezHidalgo et al., 2018). The main focus and objective of the studies for which these strains were collected was source of staphylococcal bacteremia, mainly endocarditis $(N=214)$, catheter-related bacteremia $(\mathrm{CRB})(N=212)$, skin and soft tissue infections (SSTI) $(N=66)$, and bone and joint infections $(N=100)$. Eight of these collections corresponded to $S A B$ infections in adults, and two in children $(<15$ years of age). The percentage of MRSA strains included in each collection varied. The studies were approved by the ethics committee of the University Hospital 12 de Octubre (Madrid, Spain). It was not considered necessary to obtain written informed consent because the participants were anonymized (IRH-ANT-2013-01).

Cases were classified according to acquisition: healthcareassociated (HA) or community-acquired (CA). HA included both nosocomial cases with a positive blood culture obtained from patients who had been hospitalized for $48 \mathrm{~h}$ or longer (Garner et al., 1988) and healthcare-associated cases following Friedman et al.'s criteria (Friedman et al., 2002). CA cases were those with a positive blood culture obtained at the time of hospital admission or within $48 \mathrm{~h}$ after hospital admission.

Methicillin resistance was defined on the basis of results of microdilution techniques, cefoxitin susceptibility testing and/or the presence of the mecA gene.

\section{Molecular Studies}

Blood cultures were processed with an automated blood culture system (BACTEC 9240, Becton Dickinson Microbiological System, USA). Automatic microdilution techniques were used for identification and susceptibility testing of isolates. Bacterial DNA was extracted using commercial extraction kits (Qiagen, Germany) according to the manufacturer's recommendations. DNA microarrays (Alere, Germany; Monecke et al., 2008) covering 334 target sequences and approximately 187 different genes that included species-specific markers, antimicrobial resistance genes, exotoxins, genes encoding microbial surface components recognizing adhesive matrix molecules (MCSCRAMMs), capsule genes, clonal complexes (CC) and agr group typing markers were run on the whole collection of strains. Those cases with ambiguous array results were considered as missing values for further analysis.

Only genes found with a frequency of between 5 and $95 \%$ in the whole collection were considered for statistical analysis. 
TABLE 1 | Description of the bacteremia-producing strain collections included in the study.

\begin{tabular}{|c|c|c|c|c|c|c|c|c|}
\hline Source & Period & Participating cities & $\begin{array}{l}\text { Participating } \\
\text { hospitals* }\end{array}$ & $\begin{array}{l}\text { Number } \\
\text { of strains }\end{array}$ & $\begin{array}{l}\text { Age } \\
\text { population }\end{array}$ & $\begin{array}{c}\text { MRSA } \\
(\%)\end{array}$ & Commentary & References \\
\hline Endocarditis & 2013-2016 & $\begin{array}{l}\text { Malaga, Seville, } \\
\text { Madrid, Barcelona, } \\
\text { Santander, Bilbao }\end{array}$ & 15 & 210 & Adults & 19.0 & Prospective study & $\begin{array}{l}\text { Fernández- } \\
\text { Hidalgo et al., } \\
2018\end{array}$ \\
\hline Catheter & 2011-2014 & $\begin{array}{l}\text { Madrid, Barcelona, } \\
\text { Seville }\end{array}$ & 5 & 80 & Adults & 0.0 & $\begin{array}{l}\text { Prospective study including } \\
\text { only MSSA strains }\end{array}$ & $\begin{array}{l}\text { San-Juan et al., } \\
2016\end{array}$ \\
\hline Various sources $^{a}$ & 2002-2010 & Madrid & 1 & 111 & Children & 3.6 & Retrospective studies & - \\
\hline $\begin{array}{l}\text { Various } \\
\text { sources }^{b}\end{array}$ & 2009-2010 & $\begin{array}{l}\text { Madrid, Barcelona, } \\
\text { Palma de Mallorca, A } \\
\text { Coruña }\end{array}$ & 5 & 91 & Children & 12.1 & Prospective study & - \\
\hline Various sources $^{\mathrm{C}}$ & 2006-2010 & Madrid & 1 & 45 & $\begin{array}{l}\text { Adults and } \\
\text { children }\end{array}$ & 51.1 & $\begin{array}{l}\text { Retrospective study } \\
\text { including recurrent } \\
\text { bacteremia. } \\
\text { Children } n=3\end{array}$ & - \\
\hline $\begin{array}{l}\text { Various } \\
\text { sources }^{d}\end{array}$ & 2010-2011 & Madrid & 1 & 111 & Adults & 24.3 & Retrospective study & $\begin{array}{l}\text { Viedma et al., } \\
2014\end{array}$ \\
\hline Various sources ${ }^{\mathrm{e}}$ & 2012-2014 & Madrid & 1 & 59 & Adults & 100.0 & $\begin{array}{l}\text { Retrospective study } \\
\text { including only MRSA strains }\end{array}$ & - \\
\hline $\begin{array}{l}\text { Bone and joint } \\
\text { infections }\end{array}$ & 2005-2015 & Madrid & 1 & 49 & Adults & 71,4 & Retrospective study & $\begin{array}{l}\text { Muñoz-Gallego } \\
\text { et al., } 2017\end{array}$ \\
\hline $\begin{array}{l}\text { Bone and joint } \\
\text { infections }\end{array}$ & 2016 & Madrid & 7 & 29 & Adults & 20,7 & Prospective study & - \\
\hline Colonization & 2012 & Madrid & 1 & 48 & Adults & 5.8 & $\begin{array}{l}\text { Prospective study of } \\
\text { colonization strains from } \\
\text { healthy carriers }\end{array}$ & $\begin{array}{l}\text { López-aguilera } \\
\text { et al., } 2013\end{array}$ \\
\hline
\end{tabular}

${ }^{a}$ Catheter-related, congenital, skin and soft tissue infections, osteoarticular, unknown.

$b, c, e$ Catheter-related, skin and soft tissue infections, osteoarticular, unknown.

${ }^{d}$ Catheter-related, skin and soft tissue infections, osteoarticular, endocarditis, urinary tract infection, respiratory, unknown.

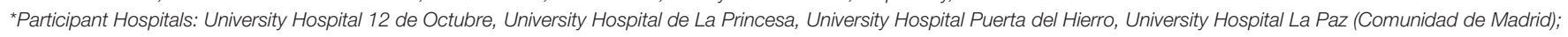

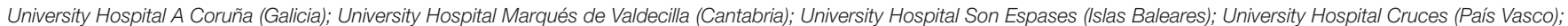

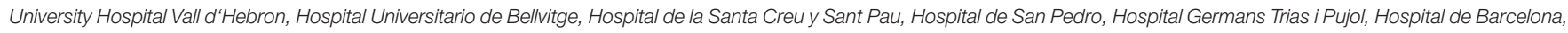
Hospital Parc Tauli (Cataluña); Hospital Universitario Virgen de la Macarena, Hospital Universitario Virgen del Rocío, Hospital Universitario Virgen de la Victoria (Andalucía).

\section{Statistical Analysis}

Categorical variables were compared using the chi-squared or Fisher's exact test, as appropriate. Significance levels of DNA microarray results were corrected using the Bonferroni correction for multiple tests. Pairwise comparisons of the main CCs, agr types and virulence genes were performed with source of bacteremia. Potential associations were investigated by univariate and multivariate logistic regression, in which CCs, agr types and virulence factors were considered as independent dichotomous variables, and source of bacteremia as the dependent variable. For multivariate analysis, variables with a $p$-value $<0.1$ in the univariate analysis were included in a backward stepwise algorithm. All statistical tests were two-tailed and a $p$-value of $<0.05$ was considered statistically significant. Analyses were performed using the SPSS statistical package, version 21.0 (SPSS Inc., Chicago, IL).

\section{RESULTS}

A total of 785 S. aureus strains causing bacteremia and 48 $S$. aureus colonizing strains were characterized in this study with the DNA microarray. Of a total of 187 genes included in the array, 67 genes were excluded from further analysis. Twenty one genes because they were found in almost all of the strains (>95\%): sarA(99.5\%), saeS(98.4\%), vraS(99.7\%), lukF(96.7\%), hl(97.5\%), hld(99.3\%), sspA(99.8\%), sspB(100\%), $\operatorname{ssp} P(99.8 \%), \quad i c a A(99.6 \%), \quad i c a C(98.4 \%), \quad i c a D(99.5 \%)$, clfA(99.6\%), clfB(99.4\%), ebpS(99.4\%), eno(99.5\%), fnbA(98.1\%), map(97.6\%), $s d r C(99.3 \%)$ and isd $(99.6 \%)$; and 47 genes because they were absent from almost all of the strains $(<5 \%)$ : $\operatorname{erm} A(4.7 \%), \quad \operatorname{erm} B(0.3 \%), \quad \ln u A(0.7 \%), \quad \operatorname{mef} A(0 \%)$, $\operatorname{vat} A(0 \%), v a t B(0 \%), \operatorname{vga} A(2.6 \%), \operatorname{vga} B(0 \%)$, aacA-aphD $(3.9 \%)$, dfrS1(2.5\%), fusB(0\%), fusC(0.8\%), tetK(2.2\%), tetM(2.1\%), cat $(0.8 \%), \quad c f r(0.1 \%), \quad f e x A(0.2 \%), \quad q a c A(0.2 \%), \quad q a c C(2.2 \%)$, $\operatorname{van} A(0 \%), \operatorname{van} B(0 \%), \operatorname{vanZ}(0 \%), \operatorname{seb}(3.6 \%), \operatorname{see}(0 \%), \operatorname{seh}(4.6 \%)$, sej(3.6\%), sek(3.4\%), seq(3.1\%), ser(3.4\%), pvl(1.8\%), etA (2.5\%), et $B(0.8 \%)$, et $D(3.1 \%)$, edin $A(0.6 \%)$, edin $B(3.3 \%)$, edin $C(0.7 \%)$, ACME cluster(0.5\%), arcA-SCC (0.2\%), arcB-SCC $(0.1 \%)$, arc$S C C(0.1 \%)$, $\operatorname{arcD}-S C C(3.6 \%)$, cap $1(0.7 \%)$, and bap $(0.1 \%)$. Nine additional genes were discarded due to an unacceptable number of missing values (>30\%): $\operatorname{mec} C(55 \%), \operatorname{mec} R(56.2 \%)$, $\operatorname{mer} A(53.3 \%)$, merB(39.5\%), fosBplasmid(62.8\%), lukM(52.8\%), $\operatorname{luk} Y(51.3 \%), \operatorname{set} C-\operatorname{sel} X(52.3 \%), \operatorname{set} B 3(51.5 \%), \operatorname{setB2}(51.7 \%)$, $\operatorname{setB1}(52.6 \%), f n b B(51.3 \%)$, and $s d r D(51.6 \%)$. 
The main CCs detected in this study were: CC5 (30.8\%), CC30 (20.3\%), CC45 (8.3\%), CC8 (8.4\%), CC15 (7.5\%) and CC22 (5.9\%). In addition, up to 22 minor CCs were also detected: CC398 (2.4\%), CC121 (2.4\%), CC25 (2.2\%), CC9 (1.7\%), CC97 (1.6\%), CC6 (1.3\%), CC1 (1.1\%), CC7 (1.1\%), CC188 (1.0\%), CC101, CC10, CC49, CC59, CC509, CC20, CC12, CC75, CC96, CC395, CC522, CC707 and CC1021 (<1\%; Table 2). agrII type was the most common (41.7\%), followed by agrI (33.7\%) and $\operatorname{agrIII}(22.2 \%)$.

\section{Distribution of $S$. aureus Strains by $\mathrm{CC}$ and agr Type According to Acquisition, Methicillin Resistance and Age of Population \\ Healthcare-Associated vs. Community-Acquired}

In our collection, there was a higher proportion of HA strains (68.4\%) compared to CA strains, which accounted for $31.6 \%$. Healthcare-associated strains were assigned to 26 different CCs, with CC5 (35.6\%) being the most common, followed by CC30 (18.6\%). The CC diversity was slightly lower among CA strains, which were assigned to 23 CCs, with CC30 (23.4\%) and CC5 (20.2\%) being the ones most commonly found (Table 2). Although most clones circulated in the healthcare and community settings, a higher proportion of CC5 was found among HA than among CA strains (35.6 vs. $20.2 \%, p<0.001$; Table 2).

The distribution of agr types is presented in Table 3. Note that while agrI was the main agr type among CA strains (31.0\% vs. $39.2 \%, p$ : 0.030 ), agrII was associated with HA acquisition, (46.6 vs. $31.8 \%, p<0.001)$.

\section{Methicillin Resistance}

Methicillin resistance was observed in $24.7 \%$ of the strains. Eleven different CCs were detected in this group, with CC5 being the main clone (79.4\%). By contrast, among the MSSA strains, all the CCs detected in our collection were represented $(N=28)$ and showed a higher clonal diversity than MRSA strains. The major clones detected among MSSA strains were CC30 (26.5\%), CC5 (14.5\%), CC45 (10.5\%) and CC15 (10.0\%). A comparison of the two groups revealed that only CC5 was associated with methicillin resistance ( 14.7 vs. $79.4 \%, p<0.001)$, whereas CC30, CC45 and CC15 were correlated with MSSA strains $(p<0.001$; Table 2).

TABLE 2 | Distribution of S. aureus clonal complexes according to place of acquisition, methicillin resistance and age of population.

\begin{tabular}{|c|c|c|c|c|c|c|c|c|c|}
\hline \multirow[b]{2}{*}{$\mathrm{CC}^{\star *}$} & \multicolumn{3}{|c|}{ Place of acquisition* } & \multicolumn{3}{|c|}{ Methicillin resistance } & \multicolumn{3}{|c|}{ Age (adult) } \\
\hline & $\begin{array}{c}\text { HA } \\
N=551 \\
n(\%)\end{array}$ & $\begin{array}{c}\text { CA } \\
N=255 \\
n(\%)\end{array}$ & $P$-value & $\begin{array}{c}\text { MSSA } \\
N=627 \\
n(\%)\end{array}$ & $\begin{array}{c}\text { MRSA } \\
N=206 \\
n(\%)\end{array}$ & $P$-value & $\begin{array}{c}\text { Adult } \\
N=628 \\
n(\%)\end{array}$ & $\begin{array}{c}\text { Children } \\
\begin{array}{c}N=205 \\
n(\%)\end{array}\end{array}$ & $P$-value \\
\hline 5 & $193(35.6)$ & $50(20.2)$ & $<0.001$ & $90(14.7)$ & $162(79.4)$ & $<0.001$ & $213(34.2)$ & $39(20.0)$ & $<0.001$ \\
\hline 8 & $38(7.0)$ & $21(8.5)$ & 0.474 & $42(6.9)$ & $20(9.8)$ & 0.179 & $45(7.2)$ & $17(8.7)$ & 0.501 \\
\hline 15 & $40(7.4)$ & $21(8.5)$ & 0.598 & $61(10.0)$ & $0(0.0)$ & $<0.001$ & $43(6.9)$ & $18(9.2)$ & 0.293 \\
\hline 22 & $35(6.5)$ & $11(4.4)$ & 0.249 & $39(6.4)$ & $9(4.4)$ & 0.291 & $39(6.3)$ & $9(4.6)$ & 0.379 \\
\hline 30 & $101(18.6)$ & $58(23.4)$ & 0.126 & 165 (26.9) & $1(0.5)$ & $<0.001$ & $113(18.2)$ & $53(27.2)$ & 0.008 \\
\hline 45 & $42(7.7)$ & $23(9.3)$ & 0.473 & 65 (10.6) & $4(2.0)$ & $<0.001$ & $50(8.0)$ & $19(9.7)$ & 0.462 \\
\hline
\end{tabular}

*27 strains did not have place of acquisition data available.

${ }^{* \star}$ Only the major clones are shown. Other clones detected in this study were: CC1(1.1\%), CC6(1.3\%), CC7(1.1\%), CC9(1.7\%), CC10(0.6\%), CC12(0.2\%), CC2O(0.4\%), CC25(2.2\%), CC49(0.6\%), CC59(0.6\%), CC75(0.1\%), CC96(0.1\%), CC97(1.6\%), CC101(0.7\%), CC121(2.4\%), CC188(1.0\%), CC395(0.1\%), CC398(2.4\%), CC509(0.5\%), CC522(0.1\%), CC707(0.1\%) and CC1021(0.1\%).

Statistically significant results are highlighted in bold.

CC, clonal complex; HA, healthcare-associated; CA, community-associated; MSSA, methicillin-susceptible S. aureus; MRSA, methicillin-resistant S. aureus.

TABLE 3 | Distribution of agr types according to place of acquisition, methicillin resistance and age of population.

\begin{tabular}{|c|c|c|c|c|c|c|c|c|c|}
\hline \multirow[b]{2}{*}{ agr type $e^{\star \star}$} & \multicolumn{3}{|c|}{ Place of acquisition* } & \multicolumn{3}{|c|}{ Methicillin resistance } & \multicolumn{3}{|c|}{ Adult age } \\
\hline & $\begin{array}{c}\text { HA } \\
N=551 \\
n(\%)\end{array}$ & $\begin{array}{c}\text { CA } \\
N=255 \\
n(\%)\end{array}$ & $P$-value & $\begin{array}{c}\text { MSSA } \\
N=627 \\
n(\%)\end{array}$ & $\begin{array}{c}\text { MRSA } \\
N=206 \\
n(\%)\end{array}$ & $P$-value & $\begin{array}{c}\text { Adult } \\
N=628 \\
n(\%)\end{array}$ & $\begin{array}{c}\text { Children } \\
N=205 \\
n(\%)\end{array}$ & $P$-value \\
\hline agrl & $169(31.0)$ & 96 (39.2) & 0.030 & $238(38.6)$ & $37(18.4)$ & $<0.001$ & 206 (33.3) & $69(34.7)$ & 0.728 \\
\hline agrll & $254(46.6)$ & $78(31.8)$ & $<0.001$ & $179(29.1)$ & $162(80.6)$ & $<0.001$ & $276(44.7)$ & $65(32.7)$ & $<0.001$ \\
\hline agrlll & $113(20.7)$ & $61(24.9)$ & 0.225 & $179(29.1)$ & $2(1.0)$ & $<0.001$ & $123(19.9)$ & $58(29.1)$ & 0.008 \\
\hline agr/V & $9(1.7)$ & $10(4.1)$ & 0.070 & $20(3.2)$ & $0(0.0)$ & 0.006 & $13(2.1)$ & $7(3.5)$ & 0.390 \\
\hline
\end{tabular}

*27 strains did not have data for place of acquisition available.

**In the whole collection there were 16 non-typable agr strains.

Statistically significant results are highlighted in bold.

HA, healthcare-associated; CA, community-associated; MSSA, methicillin-susceptible S. aureus; MRSA, methicillin-resistant S. aureus. 
With respect to agr type, agrII type was observed to be significantly associated with MRSA strains (29.1 vs. $80.6 \%$, $p<0.001)$, whereas, agrI was associated with MSSA strains (38.6 vs. $18.4 \%, p<0.001$; Table 3 ).

\section{Adult vs. Child Population}

While 28 CCs detected in this study were represented among strains isolated from adults, lower CC diversity was detected in children, with only 19 CCs identified. A comparison of clonality in the adult and children populations revealed that while CC5 was associated with strains from adults (34.2 vs. $20.0 \%$, $p<0.001)$, CC30 was significantly related to strains from the child population (18.2 vs. $27.2 \%, p<0.008$; Table 2 ).

The distribution of agr types by patient age is shown in Table 3. This analysis showed a significant association between agrII and strains from adults ( 44.7 vs. $32.7 \%, p<0.001$ ), while agrIII was associated with the child population (19.9 vs. $29.1 \%$, $p<0.008)$.

\section{Clonal Complex Diversity, agr Type and Virulence Genes Among S. aureus Strains From Different Sources of Bacteremia}

The main objective was to explore the distribution of CCs and virulence genes according to source of bacteremia. A collection of $S$. aureus strains from healthy carriers was also added to the analysis in order to evaluate potential differences between colonizing and bacteremic strains.

Remarkably, CC5 and agrII predominated in SAB from osteoarticular infections (Tables 4A,B). When we focused on antibiotic resistance genes, significant differences were identified in strains from different sources of infection for the mecA, $m s r A$, aadD, aphA3, and sat genes (Tables 4A,B). Our results seemed to indicate a higher proportion of these resistance genes among osteoarticular infections compared with other bacteremia sources. In general, significant differences for source of bacteremia and colonization were also detected in virulence genes, such as sea, sed, hla, undisrupted hlb, splE, cna, fib, and is $a$ among others.

A comparison of colonizing vs. SAB strains revealed that the sed gene was most frequently found in colonizing strains (20.8 vs. $6.7 \%, p<0.001$; Table $4 \mathrm{~B})$. This gene also had greater representation among endocarditis strains (11.4 vs. $6.1 \%$, $p: 0.031)$. In addition, the undisrupted $h l b$ gene mostly presented in CRB strains ( 41.0 vs. $20.5 \%, p<0.001$; Table 4B). The presence of MSCRAMM genes, such as $c n a, f i b, v w b$ and isaB also varied significantly according to source of SAB. While cna and $v w b$ genes had greater representation among strains from an endocarditis source ( 48.5 vs. $37.8 \%, p: 0.012$ and 99.1 vs. $94.4 \%$, $p: 0.003$, respectively), there was significant detection of fib genes (77.3 vs. $62.5 \%$, p: 0.025 ) in SSTI sources. Finally, the isaB gene was more commonly found among CRB strains (88.5 vs. $78.1 \%, p: 0.002)$ and in the SSTI bacteremia group (100 vs. 79.4\%, $p<0.001$; Table 4B).

Various regression models were performed in order to measure the role of pathogen-related molecular markers (CC, agr type and virulence genes) adjusted for different sources of bacteremia and colonization (Table 5). All adjusted models in multivariate analysis showed that these variables were the presence of agrIV type and sed gene for colonizing strains; the presence of sea, undisrupted $h l b$ and isaB genes for CRB; sed, $s p l E$ and $f i b$ genes for an endocarditis source; undisrupted $h l b$ for the SSTI group; and finally, CC5, msrA resistance gene and hla gene with respect to bacteremia from an osteoarticular source (Table 5).

\section{DISCUSSION}

The present study describes and gives a global epidemiological overview of the molecular epidemiology of a large collection of $S$. aureus strains focused on bloodstream infections in Spain over a 15-years period. In this scenario, our study provides important findings regarding the distribution of clonality and virulence genes and their association with specific sources of SAB.

Our results revealed high clonal diversity among SAB strains, although the most prevalent CCs were CC5, CC30, CC45, CC8, CC15, and CC22, which together represented $80 \%$ of all cases. Additionally, substantial differences were found between strains causing MRSA and MSSA bacteremia, which indicated that MSSA strains were much more genetically diverse than their MRSA counterparts, which is consistent with studies developed in Europe (Aamot et al., 2012; Grundmann et al., 2014) and the USA (Miko et al., 2013; Park et al., 2017). The most common clone among MSSA strains was CC30, followed by CC45 and CC15, whereas among MRSA strains, there was a significant representation of CC5 in more than $75 \%$ of strains. Similar results have been reported in Latin America (Arias et al., 2017) and Germany (Schaumburg et al., 2012), where the CC5-MRSA clone was the most prevalent in the setting of bloodstream infections. Furthermore, in our collection, CC5 was found to be significantly associated with HA acquisition and the adult population, a finding which lends support to the interest aimed at investigating the pathogenic and molecular characteristics of CC5 and those factors that enhance its spread.

Several studies have suggested that while the agrI type is the most common one among clinical isolates (van Leeuwen et al., 2000; Moore and Lindsay, 2001), others (Sakoulas et al., 2003) have determined that more than half of clinical MRSA bloodstream isolates belong to agr group II. In our collection, agrII was also associated with MRSA, which may explain the higher percentage of agrII found in the nosocomial setting and among adults, in whom the prevalence of MRSA was higher. By contrast, agrI was related to MSSA strains and CA acquisition. Interestingly, a statistically significant association was also found between agrII and agrIII and adult and child populations, respectively. These associations are probably due to the correlation between agr type and CC, since CC5 (agrII) was the majority clone among adults and CC30 (agrIII) among children.

To date, different studies have explored the association between bacterial genotype, especially $S$. aureus virulence genes, and various clinical syndromes (Gillet et al., 2002; Jarraud et al., 
TABLE 4A | Frequency of clonal complexes, agr type, resistance and virulence genes according to different sources of infection.

\begin{tabular}{|c|c|c|c|c|c|c|}
\hline Variable & $\begin{array}{l}\text { Colonization } \\
(N=48) n(\%)\end{array}$ & $\begin{array}{c}\text { CRB } \\
(N=212) n(\%)\end{array}$ & $\begin{array}{l}\text { Endocarditis } \\
(N=214) n(\%)\end{array}$ & $\begin{array}{c}\text { SSTI } \\
(N=66) n(\%)\end{array}$ & $\begin{array}{l}\text { Osteoarticular } \\
(N=100) n(\%)\end{array}$ & $P$-value ${ }^{a}$ \\
\hline \multicolumn{7}{|l|}{$\mathrm{CC}^{*}$} \\
\hline 5 & 9 (19.1) & 65 (31.3) & 47 (22.0) & 19 (29.7) & $51(51.5)$ & $<0.001$ \\
\hline 8 & $2(4.3)$ & $14(6.7)$ & 22 (10.3) & $5(7.8)$ & $3(3.0)$ & 0.236 \\
\hline 15 & $3(6.4)$ & $15(7.2)$ & $20(9.3)$ & $10(15.6)$ & $4(4.0)$ & 0.192 \\
\hline 22 & 2 (4.3) & 15 (7.2) & $16(7.5)$ & $1(1.6)$ & $7(7.1)$ & 0.435 \\
\hline 30 & $11(23.4)$ & $44(21.2)$ & $41(19.2)$ & $11(17.2)$ & $11(11.1)$ & 0.263 \\
\hline 45 & 4 (8.5) & $19(9.1)$ & 19 (8.9) & $3(4.7)$ & $6(6.1)$ & 0.736 \\
\hline \multicolumn{7}{|l|}{ agr TYPES } \\
\hline agrl & 17 (36.2) & $72(34.1)$ & 81 (38.6) & $18(28.1)$ & $28(28.3)$ & 0.342 \\
\hline agrll & $14(29.8)$ & $90(42.7)$ & 77 (36.7) & 31 (48.4) & 55 (55.6) & 0.008 \\
\hline agrlll & $12(25.5)$ & 47 (22.3) & 46 (21.9) & $14(21.9)$ & $12(12.1)$ & 0.184 \\
\hline agr/V & $4(8.5)$ & $2(0.9)$ & $6(2.9)$ & $1(1.6)$ & $4(4.0)$ & 0.087 \\
\hline \multicolumn{7}{|c|}{ ANTIBIOTIC RESISTANCE GENES } \\
\hline $\operatorname{mec} A$ & $3(6.3)$ & $54(25.5)$ & $39(18.2)$ & $16(24.2)$ & $44(44.0)$ & $<0.001$ \\
\hline blaZ & 43 (89.6) & 179 (85.2) & 181 (84.6) & 57 (86.4) & $90(90.9)$ & 0.530 \\
\hline blal & 43 (89.6) & 177 (85.1) & 191 (91.0) & 57 (86.4) & 91 (91.0) & 0.341 \\
\hline blaR & 42 (87.5) & 175 (83.3) & 177 (84.3) & 58 (87.9) & 88 (88.9) & 0.653 \\
\hline erm(C) & $2(4.2)$ & $12(9.1)$ & 7 (3.3) & 9 (13.6) & $10(10.0)$ & 0.018 \\
\hline$m s r(A)$ & $1(2.1)$ & $29(13.7)$ & $22(10.3)$ & $11(16.7)$ & $34(34.0)$ & $<0.001$ \\
\hline mphC & $1(2.1)$ & $22(18.0)$ & $21(10.0)$ & $8(17.8)$ & 32 (33.3) & $<0.001$ \\
\hline$a a d D$ & $0(0.0)$ & $29(13.7)$ & $20(9.3)$ & $13(19.7)$ & $32(32.6)$ & $<0.001$ \\
\hline aphAЗ & $1(2.1)$ & $26(12.3)$ & $12(5.6)$ & $13(19.7)$ & $26(26.3)$ & $<0.001$ \\
\hline sat & $1(2.1)$ & $23(11.0)$ & $10(4.7)$ & $12(18.5)$ & $26(26.0)$ & $<0.001$ \\
\hline mupR & $0(0.0)$ & $10(5.4)$ & $10(4.7)$ & $3(4.5)$ & $8(8.0)$ & 0.154 \\
\hline fos $B$ & 34 (70.8) & $159(75.7)$ & $153(72.2)$ & 55 (84.6) & 75 (75.0) & 0.295 \\
\hline \multicolumn{7}{|c|}{ VIRULENCE GENES } \\
\hline tst1 & $11(22.9)$ & $34(16.1)$ & $43(20.4)$ & $9(13.6)$ & $11(11.0)$ & 0.181 \\
\hline sea & $18(37.5)$ & $65(31.4)$ & $46(21.5)$ & $20(30.8)$ & $15(15.2)$ & 0.003 \\
\hline $\mathrm{sec}$ & $2(4.2)$ & $18(8.5)$ & $11(5.1)$ & $3(4.5)$ & $4(4.0)$ & 0.432 \\
\hline sed & $10(20.8)$ & $8(4.1)$ & $23(11.4)$ & $0(0.0)$ & $6(6.6)$ & $<0.001$ \\
\hline $\operatorname{seg}$ & 34 (70.8) & 158 (75.6) & $153(74.3)$ & $45(68.2)$ & $81(81.0)$ & 0.391 \\
\hline sei & 34 (70.8) & $134(72.8)$ & $147(68.7)$ & $44(67.7)$ & $80(81.6)$ & 0.151 \\
\hline sel & $2(4.2)$ & $17(8.1)$ & $11(5.1)$ & $3(4.5)$ & $4(4.0)$ & 0.533 \\
\hline selm & $36(75.0)$ & 136 (73.9) & $154(72.6)$ & $45(68.2)$ & $84(84.0)$ & 0.137 \\
\hline seln & 34 (70.8) & 139 (75.5) & $149(70.3)$ & $45(68.2)$ & $81(81.0)$ & 0.223 \\
\hline selo & 27 (56.3) & 125 (700.6) & $144(68.9)$ & $42(64.6)$ & 79 (79.0) & 0.058 \\
\hline egc & 35 (72.9) & $168(79.2)$ & $165(77.8)$ & $45(68.2)$ & $83(83.0)$ & 0.215 \\
\hline selu & $34(70.8)$ & $164(77.7)$ & $150(70.4)$ & $45(68.2)$ & $83(83.0)$ & 0.067 \\
\hline lukS & $44(91.7)$ & $183(87.6)$ & $178(86.4)$ & $63(98.4)$ & 88 (93.6) & 0.011 \\
\hline$h \lg A$ & 47 (97.9) & $196(94.2)$ & 204 (95.8) & 61 (93.8) & 97 (98.0) & 0.448 \\
\hline$l u k D$ & $24(50.0)$ & $126(59.4)$ & $120(56.1)$ & 45 (68.2) & 66 (66.0) & 0.152 \\
\hline lukE & $23(47.9)$ & 117 (55.7) & 111 (52.9) & 39 (60.0) & 67 (67.0) & 0.110 \\
\hline lukX & $41(85.4)$ & 190 (93.1) & 191 (90.5) & 63 (95.5) & 92 (92.9) & 0.325 \\
\hline hla & 40 (83.3) & 187 (88.6) & 187 (93.5) & 64 (97.0) & 97 (97.0) & 0.006 \\
\hline un-disr hlb & 9 (18.8) & $87(41.0)$ & 54 (26.6) & $8(12.1)$ & 15 (15.2) & $<0.001$ \\
\hline sak & 39 (81.3) & 136 (74.3) & 166 (79.8) & 53 (80.3) & 77 (77.0) & 0.669 \\
\hline chp & 33 (68.8) & $147(71.7)$ & $148(75.1)$ & $5(75.8)$ & $70(70.7)$ & 0.814 \\
\hline scn & 43 (89.6) & 181 (85.8) & $179(86.1)$ & 60 (90.9) & $81(81.8)$ & 0.497 \\
\hline aur & $44(91.7)$ & $123(95.3)$ & 199 (95.2) & 63 (95.5) & $91(91.9)$ & 0.686 \\
\hline splA & 24 (50.0) & 126 (59.4) & $119(56.4)$ & 45 (68.2) & $68(68.7)$ & 0.084 \\
\hline splB & $24(50.0)$ & $122(57.5)$ & $120(56.3)$ & $46(69.7)$ & 69 (69.0) & 0.044 \\
\hline splE & $20(41.7)$ & 89 (42.6) & $103(48.1)$ & 33 (50.0) & 25 (25.0) & 0.001 \\
\hline
\end{tabular}


TABLE 4A | Continued

\begin{tabular}{|c|c|c|c|c|c|c|}
\hline Variable & $\begin{array}{l}\text { Colonization } \\
(N=48) n(\%)\end{array}$ & $\begin{array}{c}\text { CRB } \\
(N=212) n(\%)\end{array}$ & $\begin{array}{l}\text { Endocarditis } \\
(N=214) n(\%)\end{array}$ & $\begin{array}{c}\text { SSTI } \\
(N=66) n(\%)\end{array}$ & $\begin{array}{l}\text { Osteoarticular } \\
(N=100) n(\%)\end{array}$ & $P$-value ${ }^{a}$ \\
\hline \multicolumn{7}{|c|}{ CAPSULE-ASSOCIATED GENES } \\
\hline cap 5 & $21(43.8)$ & $118(55.7)$ & $109(50.9)$ & 38 (57.6) & $68(68.0)$ & 0.026 \\
\hline cap 8 & $28(58.3)$ & $96(45.3)$ & $105(49.3)$ & $28(42.4)$ & $32(32.0)$ & 0.016 \\
\hline \multicolumn{7}{|c|}{ MSCRAMM GENES } \\
\hline$b b p$ & 45 (93.8) & $183(86.3)$ & $192(89.7)$ & $57(86.4)$ & 93 (93.0) & 0.273 \\
\hline cna & $26(54.2)$ & 79 (38.2) & $100(48.5)$ & $20(30.8)$ & $32(32.7)$ & 0.006 \\
\hline$e b h$ & $45(93.8)$ & $194(91.9)$ & $190(89.2)$ & $64(97.0)$ & $90(90.0)$ & 0.257 \\
\hline fib & $28(58.3)$ & $132(62.3)$ & $126(59.2)$ & $51(77.3)$ & $71(71.0)$ & 0.030 \\
\hline sasG & 2347.9 & $127(59.9)$ & $130(60.7)$ & $41(63.1)$ & $70(70.0)$ & 0.130 \\
\hline$v w b$ & $44(91.7)$ & 197 (92.9) & 212 (99.1) & 63 (96.9) & 99 (99.0) & 0.002 \\
\hline isaB & 48 (100.0) & 185 (88.5) & $111(62.7)$ & $66(100)$ & $74(76.3)$ & $<0.001$ \\
\hline
\end{tabular}

Multiple comparison.

Unknown bacteremia source (169, 20.3\%) and other bacteremia sources including respiratory, abdominal and urinary tract infections (24, 2.9\%) were not included in this analysis.

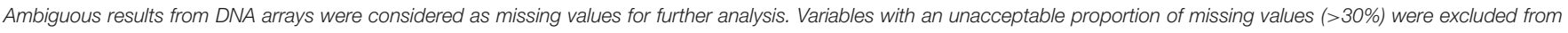
analysis.

${ }^{\star}$ Only the major clones are shown.

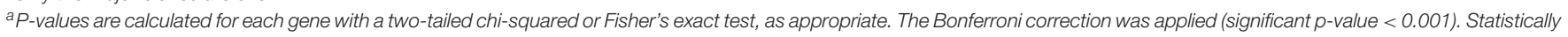
significant results are highlighted in bold.

CRB, catheter-related bacteremia; CC, clonal complex; ${ }^{\alpha}$ undisrupted hlb; MSCRAMM, microbial surface components recognizing adhesive matrix molecules.

2002; Peacock et al., 2002). This study focuses specifically on bacteremia. Our collection included S. aureus strains from the most common primary clinical sources of infection: CRB, SSTI, osteoarticular infection and endocarditis, as well as nasal carriage strains. We found no major differences between colonizing and bacteremia-producing strains of $S$. aureus, which supports the fact that most strains of $S$. aureus are capable of causing bacteremia. Nevertheless, and in accordance with other studies (Fowler et al., 2007; Giulieri et al., 2016), we identified specific clonal backgrounds and various molecular markers that have been associated with bloodstream infections and certain sources of bacteremia in particular. In this regard, our findings showed that CC5 in addition to hla and msrA genes were more frequently present in strains causing osteoarticular bacteremia. The association of the hla gene, present in most $S$. aureus strains, with different types of infection has already been reported (Stulik et al., 2014; Sharma-Kuinkel et al., 2015). Further studies are needed to elucidate the role of this important virulence factor in the pathogenesis of bacteremia. With respect to the adhesin genes (MSCRAMMs), which play an essential role in the pathogenesis of intravascular, osteoarticular and device-associated S. aureus infections (Foster et al., 2014), our study revealed an association between the $f i b$ and $i s a B$ genes and endocarditis and CRB sources, respectively. Other adhesins like $c l f A / B, f n b A / B$, and cna and their linkage with bacteremia, endocarditis and CRB, have also been reported (Giulieri et al., 2016; San-Juan et al., 2017).

Another finding of note in this study was the presence of the undisrupted $\beta$-hemolysin (undisrupted $h l b$ ) which was significantly related to sources, such as CRB and SSTI. Different studies have demonstrated its contribution to SSTI (Hedström and Malmqvist, 1982; Lebughe et al., 2017) and biofilm-related infections (Salgado-Pabón et al., 2014). Although $\beta$-toxin is encoded in $S$. aureus, most strains are reported not to secrete $\beta$-toxin because the bacteriophage ( $\phi S a 3)$ inserts into the hlb gene (Winkler et al., 1965; Coleman et al., 1991), inactivating it in the majority of $S$. aureus strains recovered from humans. Moreover, the $\phi \mathrm{Sa} 3$ bacteriophage encodes the immune evasion cluster (IEC) sak-chip-scn (Coleman et al., 1989; de Haas et al., 2004). Coinciding with other studies (Pantucek et al., 2004; Van Wamel et al., 2006), these genes were relatively abundant in our collection, ranging between $73 \%(s a k)$ and $87 \%(s c n)$. Interestingly, the absence of the intact $h l b$ gene (or which amounts to the same thing, the presence of $h l b$ truncated by the IEC-carrying $\phi S a 3$ phage) was significantly associated with an osteoarticular source. This intriguing association should be investigated further since other studies have reported the association between these phageintegrated genes and less severe staphylococcal infections (Jin et al., 2003).

This study presents several limitations that should be mentioned. First, the heterogeneity and non-continuity of the $\mathrm{SAB}$ collection (geographical origin, time points and hosts) precluded us from adjusting for these variables in multivariate analysis. Moreover, the proportion of colonization strains was small in comparison with the number of SAB strains. The results therefore should be interpreted with caution. At the same time, our study includes a large number of $S$. aureus strains causing bacteremia, with relevant information on place of acquisition, methicillin resistance and source of infection. Second, the lack of clinical data regarding the outcome of the bacteremic episodes makes it impossible to make inferences about the prognostic importance of the molecular factors. Other studies evaluating associations between bacterial genotype and virulence have led to conflicting results (Day et al., 2001, 2002; Feil et al., 2003; Melles et al., 2004), due in part to the heterogeneous nature of 
TABLE 4B | Pairwise comparison of clonal complexes, agr types and virulence genes according to source of infection.

\begin{tabular}{|c|c|c|c|c|c|c|c|c|c|c|c|c|c|c|c|}
\hline \multirow[t]{2}{*}{ Variable } & \multicolumn{3}{|c|}{$\begin{array}{l}\text { Colonization } \\
\qquad N=48\end{array}$} & \multicolumn{3}{|c|}{$\begin{array}{c}\text { CRB } \\
N=212\end{array}$} & \multicolumn{3}{|c|}{$\begin{array}{l}\text { Endocarditis } \\
\qquad N=214\end{array}$} & \multicolumn{3}{|c|}{$\begin{array}{c}\text { SSTI } \\
N=66\end{array}$} & \multicolumn{3}{|c|}{$\begin{array}{c}\text { Osteoarticular } \\
\qquad N=100\end{array}$} \\
\hline & YES & NO & $P$-value ${ }^{a}$ & YES & NO & $P$-value ${ }^{a}$ & YES & NO & $P$-value a & YES & NO & $P$-value ${ }^{a}$ & YES & NO & $P$-value ${ }^{a}$ \\
\hline \multicolumn{16}{|l|}{$\mathrm{CC}^{*}$} \\
\hline 5 & 9 (19.1) & $190(31.2)$ & 0.117 & 65 (31.3) & 134 (29.9) & 0.798 & $47(22.0)$ & $152(34.4)$ & 0.002 & 19 (29.7) & $180(30.4)$ & 1.000 & 51 (51.5) & 148 (26.6) & $<0.001$ \\
\hline 8 & $2(4.3)$ & $46(7.6)$ & 0.584 & $14(6.7)$ & $34(7.6)$ & 0.817 & 22 (10.3) & $26(5.9)$ & 0.062 & $5(7.8)$ & $43(7.3)$ & 1.000 & $3(3.0)$ & $45(8.1)$ & 0.092 \\
\hline 15 & $3(6.4)$ & 44 (93.6) & 0.788 & $15(7.2)$ & 193 (92.8) & 0.621 & $20(9.3)$ & 194 (32.2) & 0.568 & 10 (15.6) & $54(84.4)$ & 0.043 & $4(4.0)$ & 95 (96.0) & 0.114 \\
\hline 22 & $2(4.3)$ & 45 (95.7) & 0.760 & $15(7.2)$ & $193(92.8)$ & 0.685 & $16(7.5)$ & 198 (32.2) & 0.541 & $1(1.6)$ & 63 (98.4) & 0.110 & $7(7.1)$ & 92 (92.9) & 0.943 \\
\hline 30 & $11(23.4)$ & $110(18.1)$ & 0.475 & $44(21.2)$ & 77 (17.2) & 0.267 & 41 (19.2) & 80 (18.1) & 0.825 & $11(17.2)$ & $110(18.6)$ & 0.918 & $11(11.1)$ & $110(19.7)$ & 0.057 \\
\hline 45 & $4(8.5)$ & $43(91.5)$ & 1.000 & $19(9.1)$ & 189 (90.9) & 0.674 & $19(8.9)$ & 195 (91.1) & 0.789 & $3(4.7)$ & 61 (95.3) & 0.346 & $6(6.1)$ & 93 (93.9) & 0.513 \\
\hline \multicolumn{16}{|l|}{ agr TYPES } \\
\hline agrl & 17 (36.2) & 30 (63.8) & 0.934 & $72(34.1)$ & 39 (65.9) & 0.942 & 81 (38.6) & $129(61.4)$ & 0.162 & 18 (28.1) & 46 (71.9) & 0.317 & 28 (28.3) & $71(71.7)$ & 0.190 \\
\hline agrll & 14 (29.8) & $263(43.3)$ & 0.098 & $90(42.7)$ & $187(42.2)$ & 0.982 & 77 (36.7) & $200(45.0)$ & 0.052 & $31(48.4)$ & $246(41.7)$ & 0.366 & 55 (55.6) & $222(40.0)$ & 0.006 \\
\hline agrlll & $12(25.5)$ & 35 (74.5) & 0.483 & 47 (22.3) & $164(77.7)$ & 0.498 & 46 (21.9) & $164(78.1)$ & 0.608 & 14 (21.9) & 50 (78.9) & 0.900 & $12(12.1)$ & 87 (87.9) & 0.035 \\
\hline agrlV & $4(8.5)$ & $13(2.1)$ & 0.028 & $2(0.9)$ & $15(3.4)$ & 0.071 & $6(2.8)$ & $11(2.5)$ & 0.983 & $1(1.6)$ & $16(2.7)$ & 1.000 & $4(4.0)$ & $13(2.3)$ & 0.307 \\
\hline \multicolumn{16}{|c|}{ ANTIBIOTIC RESISTANCE GENES } \\
\hline mecA & $3(6.3)$ & $162(26.3)$ & 0.001 & $54(25.5)$ & $111(24.6)$ & 0.875 & $39(18.2)$ & $126(28.0)$ & 0.009 & $16(24.2)$ & $149(24.9)$ & 1.000 & $44(44.0)$ & $121(21.5)$ & $<0.001$ \\
\hline erm (C) & $2(4.2)$ & 39 (7.3) & 0.564 & $12(9.1)$ & $29(6.4)$ & 0.391 & $7(3.3)$ & $34(9.2)$ & 0.011 & $9(13.6)$ & $32(6.2)$ & 0.049 & $10(10.0)$ & $31(6.4)$ & 0.289 \\
\hline$m s r(A)$ & $1(2.1)$ & $102(16.6)$ & 0.003 & $29(13.7)$ & $74(16.4)$ & 0.444 & $22(10.3)$ & $81(18.1)$ & 0.013 & $11(16.7)$ & $92(15.4)$ & 0.934 & $34(34.0)$ & 69 (12.3) & $<0.001$ \\
\hline$m p h C$ & $1(2.1)$ & $86(17.9)$ & 0.002 & $22(18.0)$ & 65 (16.0) & 0.689 & $21(10.0)$ & $66(20.6)$ & 0.002 & $8(17.8)$ & 79 (16.3) & 0.967 & 32 (33.3) & $55(12.7)$ & $<0.001$ \\
\hline $\operatorname{aad} D$ & $0(0.0)$ & $101(16.4)$ & 0.001 & $29(13.7)$ & $72(16.0)$ & 0.517 & $20(9.3)$ & $81(18.0)$ & 0.005 & $13(19.7)$ & $88(14.7)$ & 0.377 & $32(32.6)$ & 69 (12.3) & $<0.001$ \\
\hline aphA3 & $1(2.1)$ & $81(13.2)$ & 0.021 & 26 (12.3) & $56(12.4)$ & 1.000 & $12(5.6)$ & $70(15.6)$ & $<0.001$ & $13(19.7)$ & 69 (11.6) & 0.089 & $26(26.3)$ & $56(9.9)$ & $<0.001$ \\
\hline sat & $1(2.1)$ & $76(12.4)$ & 0.033 & $23(11.0)$ & $54(12.0)$ & 0.810 & $10(4.7)$ & $67(15.1)$ & $<0.001$ & $12(18.5)$ & 65 (10.9) & 0.112 & $26(26.0)$ & $51(9.1)$ & $<0.001$ \\
\hline \multicolumn{16}{|c|}{ VIRULENCE GENES } \\
\hline sea & 18 (37.5) & 155 (25.5) & 0.098 & $65(31.4)$ & $108(24.0)$ & 0.057 & $46(21.5)$ & $127(28.7)$ & 0.063 & $20(30.8)$ & $153(25.8)$ & 0.479 & $15(15.2)$ & 158 (28.3) & 0.009 \\
\hline sed & $10(20.8)$ & $39(6.7)$ & 0.001 & $8(4.1)$ & $41(9.6)$ & 0.027 & $23(11.4)$ & $26(6.1)$ & 0.031 & $0(0.0)$ & $49(8.7)$ & 0.006 & $6(6.6)$ & $43(8.0)$ & 0.793 \\
\hline selo & 27 (56.3) & 408 (71.0) & 0.049 & 125 (70.6) & $310(69.5)$ & 0.860 & 144 (68.9) & 291 (70.3) & 0.791 & $42(64.6)$ & $393(70.4)$ & 0.410 & 79 (79.0) & $356(68.1)$ & 0.039 \\
\hline selu & $34(70.8)$ & 460 (74.9) & 0.650 & $164(77.7)$ & 330 (73.2) & 0.246 & $150(70.4)$ & 344 (76.6) & 0.106 & 45 (68.2) & 449 (75.3) & 0.264 & 83 (83.0) & 411 (73.1) & 0.049 \\
\hline lukS & $44(91.7)$ & 532 (89.1) & 0.808 & $183(87.6)$ & $393(90.1)$ & 0.392 & $178(86.4)$ & $398(90.7)$ & 0.136 & 63 (98.4) & $513(88.3)$ & 0.009 & 88 (93.6) & 488 (88.6) & 0.199 \\
\hline hla & 40 (83.3) & $559(93.0)$ & 0.032 & 187 (88.6) & $412(94.1)$ & 0.023 & 187 (93.5) & $412(91.8)$ & 0.543 & $64(97.0)$ & $535(91.8)$ & 0.218 & $97(97.0)$ & $502(91.4)$ & 0.086 \\
\hline un-disr $h / b^{\alpha}$ & $9(18.8)$ & $168(27.8)$ & 0.234 & $87(41.0)$ & 90 (20.5) & $<0.001$ & 54 (26.6) & $123(27.4)$ & 0.908 & $8(12.1)$ & 169 (28.8) & 0.006 & $15(15.2)$ & $162(29.3)$ & 0.005 \\
\hline$s p / A$ & $24(50.0)$ & $374(61.1)$ & 0.173 & $126(59.4)$ & $272(60.7)$ & 0.819 & $119(56.4)$ & 279 (62.1) & 0.187 & 45 (68.2) & $353(59.4)$ & 0.213 & 68 (68.7) & $330(58.8)$ & 0.082 \\
\hline$s p / B$ & $24(50.0)$ & $372(60.5)$ & 0.203 & $122(57.5)$ & $274(60.8)$ & 0.484 & $120(56.3)$ & 276 (61.3) & 0.254 & $46(69.7)$ & $350(58.6)$ & 0.108 & $69(69.0)$ & $327(58.1)$ & 0.052 \\
\hline splE & $20(41.7)$ & $262(42.7)$ & 1.000 & 89 (42.6) & $193(42.7)$ & 1.000 & $103(48.1)$ & $179(40.0)$ & 0.060 & $33(50.0)$ & $249(41.8)$ & 0.255 & 25 (25.0) & $257(45.8)$ & $<0.001$ \\
\hline \multicolumn{16}{|c|}{ CAPSULE-ASSOCIATED GENES } \\
\hline cap 8 & $28(58.3)$ & $272(44.2)$ & 0.082 & $96(45.3)$ & $204(45.2)$ & 1.000 & $105(49.3)$ & $195(43.3)$ & 0.175 & $28(42.4)$ & $272(45.6)$ & 0.722 & $32(32.0)$ & $268(47.6)$ & 0.005 \\
\hline \multicolumn{16}{|c|}{ MSCRAMM GENES } \\
\hline cna & $26(54.2)$ & $241(40.2)$ & 0.081 & $79(38.2)$ & $188(42.6)$ & 0.321 & $100(48.5)$ & $167(37.8)$ & 0.012 & $20(30.8)$ & $247(42.4)$ & 0.095 & $32(32.7)$ & $235(42.7)$ & 0.079 \\
\hline fib & $28(58.3)$ & $396(64.4)$ & 0.493 & $132(62.3)$ & $292(64.7)$ & 0.593 & $126(59.2)$ & $298(66.2)$ & 0.092 & $51(77.3)$ & $373(62.5)$ & 0.025 & $71(71.0)$ & $353(62.7)$ & 0.139 \\
\hline$v w b$ & $44(91.7)$ & $592(96.3)$ & 0.124 & $197(92.9)$ & $439(97.3)$ & 0.013 & $212(99.1)$ & $424(94.4)$ & 0.003 & $63(96.9)$ & 573 (95.8) & 1.000 & 99 (99.0) & $537(95.4)$ & 0.104 \\
\hline isaB & $48(100)$ & $458(80.1)$ & 0.001 & 185 (88.5) & $321(78.1)$ & 0.002 & $111(62.7)$ & 395 (89.2) & $<0.001$ & 66 (100) & $440(79.4)$ & $<0.001$ & 74 (76.3) & 432 (82.6) & 0.183 \\
\hline
\end{tabular}

*Only the major clones are shown.

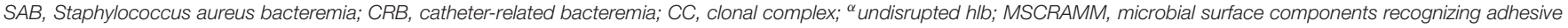
matrix molecules.

${ }^{a}$ P-values are calculated for each gene with a two-tailed chi-squared or Fisher's exact test, as appropriate. The Bonferroni correction was applied (significant p-value < 0.001).

the $S$. aureus infections included, as well as the absence of a large, well-characterized collection of isolates. Third, our study methodology was based on DNA microarrays, which should be noted in the case of the hla gene. Despite the fact that hla is present in virtually all $S$. aureus strains, some studies, such as Sharma-kuinkel et al. (JCM) have reported up to 12 different variants of hla. In our study, the hla gene was detected in $92.2 \%$ of strains. We think that the low frequency of this gene observed in our collection may have been due to the DNA microarray technology, which may underestimate the presence of certain minority hla variants due to lack of sensitivity. Whole genome sequencing may be a more effective genotypic characterization approach for detecting different genetic variants that may not be detected by hybridization procedures, although previous studies have shown good agreement between the genotypic results obtained using a DNA array-based methodology and those using high-throughput sequencing (Strauß et al., 2016). Finally, we did not perform gene expression studies, which would be key to determining whether a particular gene or set of genes was responsible for the specific pathogenic behavior observed in SAB from particular clinical sources. Nevertheless, our findings offer a valuable starting point for further research insights into intrinsic pathogenic mechanisms involved in the development of SAB.

In conclusion, the current study suggests a potential association between $S$. aureus genotype and acquisition, 
TABLE 5 | Multivariate analysis according to different sources of SAB and colonization.

\begin{tabular}{|c|c|c|c|c|c|c|c|c|c|c|}
\hline \multirow[b]{2}{*}{ Variable } & \multicolumn{2}{|c|}{ Colonization } & \multicolumn{2}{|l|}{ CRB } & \multicolumn{2}{|c|}{ Endocarditis } & \multicolumn{2}{|l|}{ SSTI } & \multicolumn{2}{|c|}{ Osteoarticular } \\
\hline & aOR $(95 \% \mathrm{Cl})$ & $P$-value & aOR (95\% Cl) & $P$-value & aOR (95\% Cl) & $P$-value & aOR (95\% Cl) & $P$-value & aOR (95\% Cl) & $P$-value \\
\hline CC5 & & & & & & & & & $2.05(1.18-3.64)$ & 0.011 \\
\hline agrlV & $4.11(1.24-13.66)$ & 0.021 & & & & & & & & \\
\hline mecA & $0.18(0.05-0.060)$ & 0.005 & & & - & - & & & & \\
\hline $\operatorname{erm}(C)$ & & & & & - & - & & & & \\
\hline sat & & & & & $0.41(0.19-0.87)$ & 0.021 & & & & \\
\hline sea & & & $2.06(1.34-3.15)$ & 0.001 & $0.57(0.34-0.96)$ & 0.035 & & & $0.39(0.21-0.72)$ & 0.003 \\
\hline sed & $5.22(1.21-12.35)$ & $<0.001$ & $0.24(0.09-0.64)$ & 0.004 & $2.79(1.33-5.85)$ & 0.007 & - & - & & \\
\hline selu & & & & & & & & & - & - \\
\hline lukS & & & & & & & & & & \\
\hline cap 8 & & & & & & & & & - & - \\
\hline cna & - & - & & & & & & & & \\
\hline fib & - & - & & & $3.42(1.63-6.44)$ & 0.001 & & & & \\
\hline$v w b$ & & & $0.35(0.15-0.80)$ & 0.013 & & & & & & \\
\hline isaB & & & $2.62(1.50-4.59)$ & 0.001 & $0.05(0.02-0.10)$ & $<0.001$ & - & - & & \\
\hline
\end{tabular}

Various multivariate models were explored that included different numbers of variables according to the number of events by bacteremia source.

-: variables included in the initial model of multivariate analysis then discarded in a backward stepwise process. Only variables consistently retained in exploratory models are shown. CRB, catheter-related bacteremia; aOR, adjusted Odds Ratio; 95\% Cl, 95\% confidence intervals; ${ }^{\alpha}$ undisrupted hlb.

methicillin resistance and bloodstream infection sources. The results of this study reinforce the view that $\mathrm{SAB}$ continues to represent a major clinical challenge. Thus, a better understanding of $S$. aureus epidemiology and pathogenesis is crucial to the detection of prognostic biomarkers as well as to the development of potential therapeutic targets aimed at improving patient outcomes.

\section{AUTHOR CONTRIBUTIONS}

DP-M, EV, and FC conceived and designed the experiments. EV, CG-G, ERG, NL, NF-H, RS, and IM-G collected the isolates. Funding was obtained by FC and BA. Experiments were performed by EV, CG-G, and IM-G. The data were analyzed by EV and DP-M. EV and DP-M prepared the manuscript draft. All authors agreed to be accountable for all aspects of the work. $\mathrm{EV}, \mathrm{DP}-\mathrm{M}$, and FC contributed in giving final approval of the version to be published. All authors reviewed and approved the final manuscript.

\section{REFERENCES}

Aamot, H. V., Blomfeldt, A., and Eskesen, A. N. (2012). Genotyping of 353 Staphylococcus aureus bloodstream isolates collected between 2004 and 2009 at a Norwegian university hospital and potential associations with clinical parameters. J. Clin. Microbiol. 50, 3111-3114. doi: 10.1128/JCM.01 352-12

\section{FUNDING}

This work was supported by the Health Research Fund, Department of Health, Spain; Agency for Health Technology Assessment and Research (PI15/02013 and PI15/02125) and Instituto de Salud Carlos III, Subdirección General de Redes y Centros de Investigación Cooperativa, Ministerio de Economía y Competitividad, Spanish Network for Research in Infectious Diseases (REIPI RD16/0016-0002; 0003; 0004) and cofunded by the European Regional Development Fund (FEDER).

\section{ACKNOWLEDGMENTS}

We thank Mercedes Murcia for excellent technical assistance, Jaime Lora-Tamayo for statistical analysis support and Janet Dawson for language support. Moreover, we thank all clinical and microbiological researchers that participated in studies that led to the collection of the Staphylococcus aureus strains presented in this study.

Arias, C. A., Reyes, J., Carvajal, L. P., Rincon, S., Diaz, L., Panesso, D., et al. (2017). A prospective cohort multicenter study of molecular epidemiology and phylogenomics of Staphylococcus aureus bacteremia in nine latin american countries. Antimicrob. Agents Chemother. 61, e00816-e00817. doi: 10.1128/AAC.00816-17

Coleman, D., Knights, J., Russell, R., Shanley, D., Birkbeck, T. H., Dougan, G., et al. (1991). Insertional inactivation of the Staphylococcus aureus 
beta-toxin by bacteriophage phi 13 occurs by site- and orientationspecific integration of the phi 13 genome. Mol. Microbiol. 5, 933-939. doi: 10.1111/j.1365-2958.1991.tb00768.x

Coleman, D. C., Sullivan, D. J., Russell, R. J., Arbuthnott, J. P., Carey, B. F., and Pomeroy, H. M. (1989). Staphylococcus aureus bacteriophages mediating the simultaneous lysogenic conversion of beta-lysin, staphylokinase and enterotoxin A: molecular mechanism of triple conversion. J. Gen. Microbiol. 135, 1679-1697.

Day, N. P., Moore, C. E., Enright, M. C., Berendt, A. R., Smith, J. M., Murphy, M. F., et al. (2001). A link between virulence and ecological abundance in natural populations of Staphylococcus aureus. Science 292, 114-116. doi: 10.1126/science.1056495

Day, N. P. J., Moore, C. E., Enright, M. C., Berendt, A. P., Smith, J. M., Murphy, M. F., et al. (2002). Retraction. Science 295:971. doi: 10.1126/science.295.5557.971b

de Haas, C. J., Veldkamp, K. E., Peschel, A., Weerkamp, F., Van Wamel, W. J., Heezius, E. C., et al. (2004). Chemotaxis inhibitory protein of Staphylococcus aureus, a bacterial antiinflammatory agent. J. Exp. Med. 199, 687-695. doi: $10.1084 /$ jem. 20031636

Feil, E. J., Cooper, J. E., Grundmann, H., Robinson, D. A., Enright, M. C., Berendt, T., et al. (2003). How clonal is Staphylococcus aureus? J. Bacteriol. 185, 3307-3316. doi: 10.1128/JB.185.11.3307-3316.2003

Fernández-Hidalgo, N., Ribera, A., Larrosa, M. N., Viedma, E., Origüen, J., de Alarcón, A., et al. (2018). Impact of Staphylococcus aureus phenotype and genotype on the clinical characteristics and outcome of infective endocarditis. A multicenter, longitudinal, prospective, observational study. Clin. Microbiol. Infect. 24, 985-991. doi: 10.1016/j.cmi.2017.12.002

Foster, T. J., Geoghegan, J. A., Ganesh, V. K., and Höök M. (2014). Adhesion, invasion and evasion: the many functions of the surface proteins of Staphylococcus aureus. Nat. Rev. Microbiol. 12, 49-62. doi: 10.1038/nrmicro3161

Fowler, V. G., Nelson, C. L., McIntyre, L. M., Kreiswirth, B. N., Monk, A., Archer, G. L., et al. (2007). Potential associations between hematogenous complications and bacterial genotype in Staphylococcus aureus infection. J. Infect. Dis. 196, 738-747. doi: 10.1086/520088

Friedman, N. D., Kaye, K. S., Stout, J. E., McGarry, S. A., Trivette, S. L., Briggs, J. P., et al. (2002). Health care-associated bloodstream infections in adults: a reason to change the accepted definition of community-acquired infections. Ann. Intern. Med. 137, 791-797. doi: 10.7326/0003-4819-137-10-20021119000007

Garner, J. S., Jarvis, W. R., Emori, T. G., Horan, T. C., and Hughes, J. M. (1988). CDC definitions for nosocomial infections, 1988. Am. J. Infect. Control 16, 128-140. doi: 10.1016/0196-6553(88)90053-3

Gillet, Y., Issartel, B., Vanhems, P., Fournet, J. C., Lina, G., Bes, M., et al. (2002). Association between Staphylococcus aureus strains carrying gene for Panton-Valentine leukocidin and highly lethal necrotising pneumonia in young immunocompetent patients. Lancet 359, 753-759. doi: 10.1016/S0140-6736(02)07877-7

Giulieri, S. G., Holmes, N. E., Stinear, T. P., and Howden, B. P. (2016). Use of bacterial whole-genome sequencing to understand and improve the management of invasive Staphylococcus aureus infections. Expert Rev. Anti Infect. Ther. 14, 1023-1036. doi: 10.1080/14787210.2016.1233815

Grundmann, H., Schouls, L. M., Aanensen, D. M., Pluister, G. N., Tami, A., Chlebowicz, M., et al. (2014). The dynamic changes of dominant clones of Staphylococcus aureus causing bloodstream infections in the European region: results of a second structured survey. Euro Surveill. 19:20987.

Hedström, S. A., and Malmqvist, T. (1982). Sphingomyelinase activity of Staphylococcus aureus strains from recurrent furunculosis and other infections. Acta Pathol. Microbiol. Immunol. Scand. B 90, 217-220. doi: 10.1111/j.1699-0463.1982.tb00108.x

Jarraud, S., Mougel, C., Thioulouse, J., Lina, G., Meugnier, H., Forey, F., et al. (2002). Relationships between Staphylococcus aureus genetic background, virulence factors, agr groups (alleles), and human disease. Infect. Immun. 70, 631-641. doi: 10.1128/IAI.70.2.631-641.2002

Jin, T., Bokarewa, M., McIntyre, L., Tarkowski, A., Corey, G. R., Reller, L. B., et al. (2003). Fatal outcome of bacteraemic patients caused by infection with staphylokinase-deficient Staphylococcus aureus strains. J. Med. Microbiol. 52, 919-923. doi: 10.1099/jmm.0.05145-0
Laupland, K. B. (2013). Incidence of bloodstream infection: a review of population-based studies. Clin. Microbiol. Infect. 19, 492-500. doi: $10.1111 / 1469-0691.12144$

Le Moing, V., Alla, F., Doco-Lecompte, T., Delahaye, F., Piroth, L., Chirouze, C., et al. (2015). Staphylococcus aureus bloodstream infection and endocarditis-a prospective cohort study. PLOS ONE 10:e0127385. doi: 10.1371/journal.pone.0127385

Lebughe, M., Phaku, P., Niemann, S., Mumba, D., Peters, G., Muyembe-Tamfum, J. J., et al. (2017). The impact of the Staphylococcus aureus virulome on infection in a developing country: a cohort study. Front. Microbiol. 8:1662. doi: $10.3389 /$ fmicb.2017.01662

López-aguilera, S., Go, M., Barrado, L., González-rodríguez-salinas, M. C., Otero, J. R., and Chaves, F. (2013). Colonización nasal por Staphylococcus aureus en estudiantes de medicina: importancia en la transmisión hospitalaria. Enfermedades Infecciosas Microbiol. Clín. 31, 500-505. doi: 10.1016/j.eimc.2012.12.005

Melles, D. C., Gorkink, R. F. J., Boelens, H. A. M., Snijders, S. V., Peeters, J. K., Moorhouse, M. J., et al. (2004). Natural population dynamics and expansion of pathogenic clones of Staphylococcus aureus. J. Clin. Invest. 114, 1732-1740. doi: $10.1172 /$ JCI200423083

Miko, B. A., Hafer, C. A., Lee, C. J., Sullivan, S. B., Hackel, M. A., Johnson, B. M., et al. (2013). Molecular characterization of methicillin-susceptible Staphylococcus aureus clinical isolates in the united states, 2004 to 2010. J. Clin. Microbiol. 51, 874-879. doi: 10.1128/JCM.00923-12

Monecke, S., Slickers, P., and Ehricht, R. (2008). Assignment of Staphylococcus aureus isolates to clonal complexes based on microarray analysis and pattern recognition. FEMS Immunol. Med. Microbiol. 53, 237-251. doi: 10.1111/j.1574-695X.2008.00426.x

Moore, P. C., and Lindsay, J. A. (2001). Genetic variation among hospital isolates of methicillin-sensitive Staphylococcus aureus: evidence for horizontal transfer of virulence genes. J. Clin. Microbiol. 39, 2760-2767. doi: 10.1128/JCM.39.8.2760-2767.2001

Muñoz-Gallego, I., Lora-Tamayo, J., Pérez-Montarelo, D., Bra-as, P., Viedma, E., and Chaves, F. (2017). Influence of molecular characteristics in the prognosis of methicillin-resistant Staphylococcus aureus prosthetic joint infections: beyond the species and the antibiogram. Infection 45, 533-537. doi: 10.1007/s15010-017-1011-6

Pantucek, R., Doskar, J., Ruzicková, V., Kaspárek, P., Orácová, E., Kvardová, V., et al. (2004). Identification of bacteriophage types and their carriage in Staphylococcus aureus. Arch. Virol. 149, 1689-1703. doi: 10.1007/s00705-004-0335-6

Park, K. H., Greenwood-Quaintance, K. E., Uhl, J. R., Cunningham, S. A., Chia, N., Jeraldo, P. R., et al. (2017). Molecular epidemiology of Staphylococcus aureus bacteremia in a single large Minnesota medical center in 2015 as assessed using MLST, core genome MLST and spa typing. PLoS ONE 12:e0179003. doi: 10.1371/journal.pone.0179003

Peacock, S. J., Moore, C. E., Justice, A., Kantzanou, M., Story, L., Mackie, K., et al. (2002). Virulent combinations of adhesin and toxin genes in natural populations of Staphylococcus aureus. Infect. Immun. 70, 4987-4996. doi: 10.1128/IAI.70.9.4987-4996.2002

Recker, M., Laabei, M., Toleman, M. S., Reuter, S., Saunderson, R. B., Blane, B., et al. (2017). Clonal differences in Staphylococcus aureus bacteraemia-associated mortality. Nat. Microbiol. 2, 1381-1388. doi: 10.1038/s41564-017-0001-x

Sakoulas, G., Eliopoulos, G. M., Moellering, R. C., Novick, R. P., Venkataraman, L., Wennersten, C., et al. (2003). Staphylococcus aureus accessory gene regulator (agr) group II: is there a relationship to the development of intermediatelevel glycopeptide resistance? J. Infect. Dis. 187, 929-938. doi: 10.1086/ 368128

Salgado-Pabón, W., Herrera, A., Vu, B. G., Stach, C. S., Merriman, J. A., Spaulding, A. R., et al. (2014). Staphylococcus aureus $\beta$-toxin production is common in strains with the $\beta$-toxin gene inactivated by bacteriophage. J. Infect. Dis. 210 , 784-792. doi: 10.1093/infdis/jiu146

San-Juan, R., Pérez-Montarelo, D., Viedma, E., Lalueza, A., Fortún, J., Loza, E., et al. (2017). Pathogen-related factors affecting outcome of catheterrelated bacteremia due to methicillin-susceptible Staphylococcus aureus in a Spanish multicenter study. Eur. J. Clin. Microbiol. Infect. Dis. 36, 1757-1765. doi: 10.1007/s10096-017-2989-5 
San-Juan, R., Viedma, E., Chaves, F., Lalueza, A., Fortún, J., Loza, E., et al. (2016). High MICs for vancomycin and daptomycin and complicated catheter-related bloodstream infections with methicillin-sensitive Staphylococcus aureus. Emerg. Infect. Dis. 22, 1057-1066. doi: 10.3201/eid2206.151709

Schaumburg, F., Köck, R., Mellmann, A., Richter, L., Hasenberg, F., Kriegeskorte, A., et al. (2012). Population dynamics among methicillin-resistant Staphylococcus aureus isolates in Germany during a 6-year period. J. Clin. Microbiol. 50, 3186-3192. doi: 10.1128/JCM.01174-12

Sharma-Kuinkel, B. K., Wu, Y., Tabor, D. E., Mok, H., Sellman, B. R., Jenkins, A., et al. (2015). Characterization of alpha-toxin hla gene variants, alpha-toxin expression levels, and levels of antibody to alpha-toxin in hemodialysis and postsurgical patients with Staphylococcus aureus. J. Clin. Microbiol. 53, 227-236. doi: 10.1128/JCM.02023-14

Shorr, A. F., Tabak, Y. P., Killian, A. D., Gupta, V., Liu, L. Z., and Kollef, M. H. (2006). Healthcare-associated bloodstream infection: a distinct entity? Insights from a large U.S. database. Crit. Care Med. 34, 2588-2595. doi: 10.1097/01.CCM.0000239121.09533.09

Strauß, L., Ruffing, U., Abdulla, S., Alabi, A., Akulenko, R., Garrine, M., et al. (2016). Detecting Staphylococcus aureus virulence and resistance genes: a comparison of whole-genome sequencing and DNA microarray technology. J. Clin. Microbiol. 54, 1008-1016. doi: 10.1128/JCM.03022-15

Stulik, L., Malafa, S., Hudcova, J., Rouha, H., Henics, B. Z., Craven, D. E., et al. (2014). $\alpha$-hemolysin activity of methicillin-susceptible Staphylococcus aureus predicts ventilator-associated pneumonia. Am. J. Respir. Crit. Care Med. 190, 1139-1148. doi: 10.1164/rccm.201406-1012OC

van Hal, S. J., Jensen, S. O., Vaska, V. L., Espedido, B. A., Paterson, D. L., and Gosbell, I. B. (2012). Predictors of mortality in Staphylococcus aureus bacteremia. Clin. Microbiol. Rev. 25, 362-386. doi: 10.1128/CMR.05022-11

van Leeuwen, W., van Nieuwenhuizen, W., Gijzen, C., Verbrugh, H., and van Belkum, A. (2000). Population studies of methicillin-resistant and -sensitive Staphylococcus aureus strains reveal a lack of variability in the agrD gene, encoding a staphylococcal autoinducer peptide. J. Bacteriol. 182, 5721-9. doi: 10.1128/JB.182.20.5721-5729.2000
Van Wamel, W. J. B., Rooijakkers, S. H. M., Ruyken, M., Van Kessel, K. P. M., and Van Strijp, J. A. G. (2006). The innate immune modulators staphylococcal complement inhibitor and chemotaxis inhibitory protein of Staphylococcus aureus are located on $\beta$-hemolysin-converting bacteriophages. J. Bacteriol. 188, 1310-1315. doi: 10.1128/JB.188.4.1310-1315.2006

Viedma, E., Sanz, F., Orellana, M. A., San Juan, R., Aguado, J. M., Otero, J. R., et al. (2014). Relationship between agr dysfunction and reduced vancomycin susceptibility in methicillin-susceptible Staphylococcus aureus causing bacteraemia. J. Antimicrob. Chemother. 69, 51-58. doi: 10.1093/jac/dkt337

Weiner, L. M., Webb, A. K., Limbago, B., Dudeck, M. A., Patel, J., Kallen, A. J., et al. (2016). Antimicrobial-resistant pathogens associated with healthcareassociated infections: summary of data reported to the national healthcare safety network at the centers for disease control and prevention, 2011-2014. Infect. Control Hosp. Epidemiol. 37, 1288-1301. doi: 10.1017/ice.2016.174

Winkler, K. C., de Waart, J., Grootsen, C., Zegers, B. J. M., Tellier, N. F., and Vertregt, C. D. (1965). Lysogenic conversion of staphylococci to loss of betatoxin. J. Gen. Microbiol. 39, 321-333. doi: 10.1099/00221287-39-3-321

Wyllie, D. H. (2006). Mortality after Staphylococcus aureus bacteraemia in two hospitals in Oxfordshire, 1997-2003: cohort study. BMJ 333, 281-280. doi: $10.1136 / \mathrm{bmj} .38834 .421713 .2 \mathrm{~F}$

Conflict of Interest Statement: The authors declare that the research was conducted in the absence of any commercial or financial relationships that could be construed as a potential conflict of interest.

Copyright (๔ 2018 Pérez-Montarelo, Viedma, Larrosa, Gómez-González, Ruiz de Gopegui, Muñoz-Gallego, San Juan, Fernández-Hidalgo, Almirante and Chaves. This is an open-access article distributed under the terms of the Creative Commons Attribution License (CC BY). The use, distribution or reproduction in other forums is permitted, provided the original author(s) and the copyright owner(s) are credited and that the original publication in this journal is cited, in accordance with accepted academic practice. No use, distribution or reproduction is permitted which does not comply with these terms. 